\title{
DE ASILO A HOSPITAL DOS TIFOSOS: O CASO DO ASILO ANTÓNIO ALMEIDA DA COSTA NA PRIMEIRA METADE DO SÉCULO XX. GÉNESE, DINÂMICAS E FUNCIONALIDADES
}

\author{
Catarina Nogueira Pereira \\ Arquivo e Centro de Documentação da Misericórdia de Gaia, Vila Nova de Gaia, Portugal \\ Email: catarina nogueira@live.com.pt \\ ORCID iD: https://orcid.org/0000-0002-6954-4570 \\ Diogo Guedes Vidal \\ Unidade de Investigação UFP em Energia, Ambiente e Saúde, Universidade Fernando Pessoa, Porto, Portugal \\ Email: diogoguedesvidal@hotmail.com \\ ORCID iD: https://orcid.org/0000-0002-2777-2372
}

Recibido: 11 diciembre 2019; Aceptado: 4 febrero 2020

\begin{abstract}
Cómo citar este artículo/Citation: Pereira, Catarina Nogueira; Vidal, Diogo Guedes (2020) "De asilo a hospital dos Tifosos: O caso do asilo António Almeida da Costa na primeira metade do século XX. Génese, dinâmicas e funcionalidades", Asclepio, $72(2)$ : p318. https://doi.org/10.3989/asclepio.2020.19

RESUMO: O presente trabalho tem como objetivos principais analisar a génese, as dinâmicas e as funcionalidades do Asilo António Almeida da Costa, fundado no início do século XX em Vila Nova de Gaia, localidade perto da cidade do Porto, no norte de Portugal, na assistência na velhice, inicialmente idealizada para os velhos operários do complexo industrial de Cerâmica e de Fundição das Devesas, e na sua iniciativa pontual: a transformação num hospital dos Tifosos aquando a epidemia que se fez sentir na cidade. Para responder a estes objetivos efectuou-se um exercício de reconstrução histórica através do acervo do benemérito, nomeadamente com base nas atas da comissão administrativa, nos regulamentos e estatutos internos e, também, no livro de inválidos internados no Asilo. Com base na informação encontrada foi possível descrever as dinâmicas da instituição na assistência à velhice, em especial no lugar das Devesas em Vila Nova de Gaia, enquadrando o importante contributo da mesma na causa pública do combate à epidemia do tifo exantemático.
\end{abstract}

PALAVRAS CHAVE: assistência; velhice; operários; tifo

\author{
FROM ASYLUM TO A TYPHOUS HOSPITAL: THE CASE OF THE ASYLUM ANTÓNIO ALMEIDA DA COSTA IN \\ THE FIRST HALF OF THE TWENTIETH CENTURY. GENESIS, DYNAMICS AND FUNCTIONALITIES
}

ABSTRACT: This work aims to analyse the genesis, dynamics and functionalities of the António Almeida da Costa Asylum, founded at the beginning of the 20th century in Vila Nova de Gaia, in northern Portugal, in the elderly assistance, initially funded for the elderly workers of the industrial complex of Ceramics and Foundry of Devesas, and in their punctual initiative: the transformation into a hospital for the Typhosos when the epidemic occurred in the city. To meet these objectives, a historical reconstruction exercise was carried out through the benemerit acquis, in particular, based on the minutes of the administrative committee, in internal regulations and statutes and also in the book of invalids hospitalized in the Asylum. Based on the information found, it was possible to describe the institution's dynamics in the assistance to the elderly, especially in the place of the Devesas in Vila Nova de Gaia, framing the important contribution of it in the public cause of the fight against the exanthematic typhus epidemic.

KEY WORDS: Assistance; Elderly; Workers; Typhus

Copyright: (C) 2020 CSIC. Este es un artículo de acceso abierto distribuido bajo los términos de la licencia de uso y distribución Creative Commons Reconocimiento 4.0 Internacional (CC BY 4.0) 


\section{INTRODUÇÃO}

Um balanço da literatura acerca da pobreza e dos limites de sobrevivência, na viragem do século XIX para o século $X X$, em Portugal, aponta para uma realidade social e económica de debilidade, vivida por alguns grupos da população com escassos recursos económicos, frente a desafios de sobrevivência ${ }^{1}$. As razões para tal têm sido associadas às deficientes condições de vida (alimentação, rendimentos) e às habitações insalubres (Cascão, 2011, p. 31) que contribuíam para que uma população, exposta a situações de doença e ambientes propícios, atingisse elevadas taxas de mortalidade. As razões têm sido focadas na fragilidade da proteção social, que, à época, ainda não integrava uma das missões do Estado, enquanto direito universal, pelo facto da 1a República, ainda que implementada em 1910, se assumir como um órgão débil e em constante instabilidade ${ }^{2}$ (Rosas y Rollo, 2009).

A pobreza é constante no processo evolutivo das sociedades. Ela altera-se, modifica-se e molda-se consoante o espaço e tempo. A pobreza é, em parte, um estado de nada ter, cujos critérios evoluíram, entre uma necessidade de consumo básico e a irregular distribuição da riqueza e de recursos, que pode levar à exclusão e à marginalidade (Fernandes, 2018, p. 59). Ser pobre, ao longo dos tempos e da própria história, significou estar desintegrado da esfera social, incapaz para o trabalho, de contribuir, de ter um lugar e de ser parte ativa do meio onde o pobre se insere. Estas situações, quando reconhecidas pela sociedade, atribuem o rótulo de pobre. A condição de pobreza só existe quando lhe é prestada assistência. A assistência só existe porque existem os assistidos. Neste sentido, e como Teixeira Fernandes refere, não é ter falta de recursos ou a impossibilidade de adquiri-los que torna um indivíduo pobre: o que torna a pessoa pobre é a assistência que recebe (Fernandes, 2018, p. 61). O combate às formas de pobreza esteve, desde sempre, muito ligado à caridade praticada pelas famílias locais com mais posses económicas (Araújo y Esteves, 2011, p. 233). Seria uma forma de alcançar o "céu", de praticar o bem na terra e de fomentar um espírito de superioridade positiva sobre os mais vulneráveis. Aliadas ao conceito de pobreza surgem as práticas de atenção à mendicidade, vagabundagem e criminalidade. O contexto de inserção do indivíduo vai condicionar o tipo de pobre. Se nas comunidades rurais ser pobre é uma condição quase "natural", em que a preocupação era inexistente pois os laços so- ciais de entreajuda entre a comunidade prevaleciam e os meios de sobrevivência estavam disponíveis nomeadamente da agricultura -, ser pobre na cidade era ser alvo de punição social, de desprezo e descrédito pois a forma de organização da vida social difere da do campo, sobretudo com a concentração urbana dos finais do século XVIII (Fernandes, 2018, p. 60).

A historiografia portuguesa tem já um longo percurso de estudo da organização da assistência à situação de pobreza. Segundo Sanglard e Lopes (2018, p. 281) a sua organização esteve sob a tutela da ações pias das irmandades devocionais e/ou de confrarias profissionais, não esquecendo o predominante papel da Igreja. À medida que o tempo passava, a perceção sobre a pobreza foi alvo de transformações induzidas pelo surgimento das novas grandes questões sociais, muito relacionadas com o desenvolvimento da vida urbana e da própria industrialização (Esteves, 2017, p. 57).

Segundo Mária de Fátima Reis (2016a), o conceito de beneficência surgiu em meados de oitocentos, com o intuito de substituir a caridade, enquanto função do Estado. $O$ assistencialismo refere-se a uma intervenção num indivíduo sem que isso obrigue a um compromisso de erradicação da situação em que se encontra, ou seja, não pressupõe mudança nem que se altere a sua condição. Caridade é uma prática historicamente ligada à prática religiosa - prática caritativa - que pressupõe um carácter de amparo aos menos favorecidos. É, ao contrário do assistencialismo, um processo contínuo que visa a transformação da condição do indivíduo. Nas palavras de Teixeira Fernandes, "por caridade, entende-se a virtude teologal que faz amar Deus e o próximo. Quem dá aos pobres terá um tesouro nos Céus." (Fernandes, 2018, p. 64). Por esta razão, assistencialismo aproxima-se de filantropia. O conceito de filantropia, surgido a partir da segunda metade do século XVIII, tem a sua origem nas raízes da racionalização da condição humana e do próprio lluminismo (Lopes, 2000, pp. 63-64), substituindo as ações caritativas por uma política estatal (Fernandes, 2018, p. 71). Distancia-se da caridade, pelo facto de pressupor a promoção do autor da filantropia, justificando-se a publicidade da sua ação pela necessidade de mobilizar e sensibilizar a sociedade em prol de um problema social, questionando as desigualdades humanas. Ancorada num sentido moralizador, a filantropia começou por abranger ações relativas à prevenção dos "males causados pela indigência", tais como a recuperação dos presos 
(Esteves, 2015b, 2015a, 2018), a assistência aos órfãos e aos loucos, a higiene pública, as caixas económicas e as sociedades de socorros mútuos (Sanglard \& Lopes, 2018, p. 282).

A filantropia começou a ganhar terreno e importância política e social. A industrialização, concomitante ao surgimento de uma nova classe de pobres - o proletariado -, traz consigo a possibilidade do patronato exercer, para além da assistência aos trabalhadores, fidelização da mão-de-obra (Fernandes, 2018, p. 72). Segundo Teixeira Fernandes “... os patrões serviam-se da filantropia com o objetivo de moralizar os trabalhadores, criando o operário regular no trabalho e disciplinado nos costumes." (Fernandes, 2018, p. 72). Inserem-se a este nível, e até estabelecendo aqui uma ponte com o objeto deste trabalho, os múltiplos benefícios que os patrões proporcionavam aos seus empregados, muito fruto do advento do bem-estar social, promovido pelo Estado (séculos $\mathrm{XIX} / \mathrm{XX}$ ), materializado na higiene dos corpos e dos lares, nos inválidos, órfãos/crianças, viúvas e idosos (Sanglard \& Lopes, 2018, p. 282). Tais questões percorreram um longo caminho e remetem para os debates dos finais do século XVI, na valorização do trabalho humano, entre a mera responsabilidade das instituições eclesiásticas, na resposta à pobreza, e uma questão social que exigia uma resposta comunitária, em que a administração pública e o estado assumiam uma forma de regulamentar a pobreza, que podia resvalar para a vagabundagem e a violência (Amorim y Pinto, 2018). Uma figura incontornável nesta linha e neste período, ainda que se apresente apenas em breves notas, é Dona Maria Amélia Luísa Helena de Bourbon-Orleães, a última Rainha de Portugal de facto. Dos seus trabalhos voltados em favor do serviço social destacam-se a fundação: da Assistência Nacional aos Tuberculosos que tornou a assistência pragmática, pondo em funcionamento dispensários distribuídos por vários distritos do país; dos Sanatórios de Santana e do Outão (à beira-mar), o de Sousa Martins (Guarda) e um em Braga; o hospital do Rego para crianças; as Cozinhas Económicas; os Socorros a Náufragos; o Instituto do Ultramar; e o Instituto Bacteriológico Câmara Pestana (para preparação do soro anti-rábico e antidiftérico) (Durães, 2019).

O presente trabalho tem como objetivos principais analisar a génese, as dinâmicas e as funcionalidades do Asilo António Almeida da Costa, fundado no início do século XX em Vila Nova de Gaia, perto da cidade do Porto, no norte de Portugal, na assistência na veIhice, inicialmente idealizada para os velhos operários do complexo industrial de Cerâmica e de Fundição das Devesas, e na sua iniciativa pontual: a transformação num hospital dos Tifosos aquando a epidemia que se fez sentir na cidade ${ }^{3}$.

As fontes utilizadas para responder aos objetivos traçados foram consultadas essencialmente: no Arquivo Municipal de Vila Nova de Gaia (Arquivo Municipal Sophia de Mello Breyner) onde se encontra depositado o "Testamento cerrado de António de Almeida e Costa", de 1915 e o "Testamento cerrado de Emília de Jesus Costa", de 1901; no Arquivo Distrital do Porto encontramos os "Estatutos do Asylo, Creche e Hospital, particulares instituidos pelos benemeritos D. Emilia de Jesus Costa e Antonio Almeida da Costa" que abordam os estatutos/funções da Instituição, contendo 27 artigos, o "Regulamento interno do Asilo, Creche e Hospital D. Emilia de Jesus Costa e Antonio Almeida da Costa" que aborda as regras internas da instituição, tanto do asilo, como dos empregados, da diretoria, do pessoal assalariado, das correções e castigos, da creche, da admissão das crianças, os deveres das mães, os empregados e os seus deveres, a alimentação das crianças, a inspeção, as prescrições higiénicas, da comissão zeladora, da administração e, por fim, das disposições gerais e transitórias e o Projeto de Estatutos da Associação das Creches de Santa Marinha; por fim no Arquivo e Centro de Documentação da Santa Casa da Misericórdia de Gaia (fiel depositário da herança de António Almeida da Costa e de Emília de Jesus Costa) viemos a localizar vários documentos relativos às dinâmicas e funcionalidades do asilo, creche e hospital, tais como o Livro de Inválidos Internados no Asilo, o Livro de Registos Individuais de Asilados e as Atas da Comissão Administrativa que têm como âmbito e conteúdo o registo das decisões tomadas nas reuniões da comissão administrativa do Asilo, Creche e Hospital D. Emília de Jesus Costa e António Almeida da Costa.

O tratamento da informação obedeceu a uma consulta e análise das fontes primárias, altura em que foi necessário transcrever a informação dos documentos originais e organizá-la em temáticas de forma a conseguir responder aos objetivos traçados; posteriormente, e após quantificada a informação encontrada, procedeu-se à construção de uma base de dados em SPSS (IBM ${ }^{\circledR}$ Statistics for Windows v.25.0) com os dados constantes nos registos de admissão 
do asilo. A construção desta base de dados permitiu, para além de facilitar o tratamento geral da informação, abordar de forma estatística os dados, através do cálculo das principais medidas de estatística descritiva - média, desvio-padrão e frequências -, e cruzar as variáveis disponíveis.

\section{O ASILO COMO OBRA DE PREVENÇÃO}

Até ao século XIX, a noção de velhice era inexistente como hoje a entendemos (Esteves, 2017, p. 58). Por este motivo, o reconhecimento das características ao "ser velho" careciam de definições que tomassem em consideração a vulnerabilidade e a desproteção. Assim, fruto deste não reconhecimento da importância do amparo nesta fase da vida humana, a falta do que hoje se designa por equipamentos sociais, com vista a estes fins, é notória.

A expansão industrial e o crescimento populacional fazem das cidades espaços protagonistas de sobrelotação, dado que as mesmas não possuíam as infraestruturas necessárias, ao nível da habitação e saneamento, para dar resposta a este fenómeno. Neste sentido, e fruto de um trabalho assalariado mal remunerado e em situação de vulnerabilidade económica, os operários assumem-se como um grupo urbano em crescimento, ainda que escasso no decorrer do século XIX, sendo somente maioritário no século XX (Lopes y Roque, 2000, p. 69; Pereira, 2003, p. 140). Esta situação social é retratada em várias obras da historiografia portuguesa, nomeadamente pela urgência social que houve em dar resposta a estes novos problemas que se afiguraram como os mais emergentes do século XIX (Esteves, 2015b). Conceitos como o de assistência, associação, expostos, greves, indústria, mendicidade, misericórdias, socialismo e trabalho são amplamente discutidos pelos historiadores (Lopes \& Roque, 2000, p. 66). Apesar das discussões em torno destes conceitos, importa aprofundar outros, direta ou indiretamente relacionados com estes fenómenos, concretamente a assistência na velhice e o amparo nesta idade. A este respeito, os conceitos de asilo e de asilado ganham especial relevo. Se no contexto medieval ao conceito de asilo se atribuíam privilégios de abrigo a todos os crimes, contra a ação da justiça, na modernidade o mesmo ganha novo sentido de abrigo, desta vez especificamente para indivíduos em situação de vulnerabilidade, seja por doença, idade ou miséria, considerações de um estudo de inícios do século XX, de Victor Ri- beiro (Ribeiro, 1907, p. 141). Segundo este autor (Victor Maximiano Ribeiro - 1862-1930), que conviveu com a realidade envolvente e assumiu responsabilidades de arquivista na Misericórdia do Porto (Reis, 2016b), na sua obra "História da beneficência pública em Portugal" (1907) considera que os asilos podiam assumir três finalidades: uma primeira que se destinava a asilar pobres, velhos, inválidos, incuráveis ou entrevados em situação de pobreza ou desamparo familiar; uma segunda, voltado para o recolhimento de mendigos e vagabundos; e, por fim, uma terceira dedicada aos cegos, surdos-mudos, consideradas enfermidades que colocam estes indivíduos em situação de privação "...das maiores e melhores alegrias da vida humana." (Ribeiro, 1907, p. 142). Como veremos, no estudo de caso, que não será o único exemplo, os asilos terão especificidades próprias, muito claras.

Ribeiro (1907), ao fazer o historial da beneficência, considera que a origem da criação dos asilos remonta ao ano de 1836, ao ministério de Luís da Silva Mouzinho de Albuquerque, período do liberalismo. Mouzinho de Albuquerque, considerando a mendicidade como um dos maiores flagelos sociais que poderia conduzir a práticas ilícitas, cria o Asylo de Mendicidade (de Lisboa) para os dois sexos, como forma de dar resposta a um problema nas cidades (Ribeiro, 1907, pp. 143-144). Herdeiras de várias heranças privadas, como parece ser o caso de António Almeida da Costa e esposa, que acabou por ser administrado pela Misericórdia de Gaia, as Misericórdias foram, em muitas localidades, responsáveis pela gerência da assistência e beneficência (Ribeiro, 1907, p. 102). As mesmas ocupavam um papel de relevo na assistência concelhia, devido à longa tradição secular de beneficência “... junto dos desventurados, mitigando-lhes as suas dores e os seus infortúnios." (Paiva \& Fontes, 2002, p. 123).

Sendo Portugal um país maioritariamente católico, cerca de 5 milhões em 1905 (Dix, 2010, p. 13), ainda que agastado pelo contexto político e social da primeira república, a disseminação da caridade por via da ação da igreja tinha uma influência considerável, na medida em que se inseria numa linha multisecular de serviço aos pobres como veículo de salvação da alma (Esteves, 2017, p. 59). A este respeito, as doações e as obras beneméritas ganham terreno na proteção dos mais vulneráveis, para além de servirem como veículo de auto-reconhecimento dos próprios benfeitores dentro da comunidade (Esteves, 2018, p. 286; Lopes, 2013, p. 271). Na verdade, como escreve Maria Antónia Lopes, entende-se que o uso da palavra beneficência 
estava relacionada com um "ato de bondade" vinculado à religião católica e a Deus (Lopes, 2000). No século XIX, o conceito de caridade dá lugar ao de filantropia, enquanto "doutrina que encarava a felicidade humana como uma construção alcançável através da prática de atos altruístas e humanitários, que teriam como objetivo último atenuar ou mesmo eliminar as injustiças sociais." (Esteves, 2015b, pp. 181-182). A filantropia, enquanto ato que surge de um sentimento de dever para com a sociedade, é acionada pelos notáveis e respeitados de uma região. Apesar de este conceito ainda ser utilizado no século $\mathrm{XX}$, a verdade é que o mesmo foi, de forma gradual, sendo substituído pelo conceito de serviço social, cujo principal objetivo era dotar a pobreza, o crime, a miséria e as doenças de uma certa profilaxia. O seu mentor foi Richard Cabot, que na realidade portuguesa deu um importante contributo através da criação da primeira Escola de Serviço Social (Silva, 2016).

\section{CARATERIZAÇÃO DO ASILO ANTÓNIO ALMEIDA DA COSTA}

A história deveria começar por D. Emília de Jesus Costa aquela que, verdadeiramente, tomou a iniciativa de legar, em testamento cerrado, as suas últimas vontades, das quais constavam do Asilo. Pouco se sabe do seu percurso, e os dados nem sempre são fundamentados em fontes referenciadas. Terá nascido em S. Ildefonso, da cidade do Porto, com o nome de Emília de Jesus Maria (filha de Silvestre de Macedo e Maria de Lima), e casado com António Almeida da Costa a 27 de fevereiro de $1855^{4}$. Se nasceu em 1837 (Portela, 2007, p. 42), teria 18 anos e o marido 23 anos quando se casaram. Nada mais se sabe sobre esta senhora, falecida em 7 de Setembro de 1914, como consta na lápide do cemitério de Santa Marinha ${ }^{5}$, em Vila Nova de Gaia.

Sobre António Almeida da Costa sabe-se mais, dado o seu percurso associado ao processo de industrialização de Gaia. Nasceu em 7 de dezembro de 1832, na freguesia de S. Domingos de Rana, concelho de Cascais, numa família de canteiros (Portela, 2007, p. 41). Pouco se sabe sobre a sua trajetória pessoal e profissional até ao momento em que veio, em 1851 (com 19 anos) para a cidade do Porto, trabalhar com Emídio Amatucci, dono de uma oficina de mármore da cidade. Em 1855, já possuía uma formação escolar em ornato e modelação, sendo o primeiro canteiro na cidade com a formação concluída (Portela, 2007, p. 42), altura em que viria a casar. As informações encontradas (Portela, 2007, pp. 42-43) indicam que se estabeleceu numa pequena oficina na Rua do Laranjal, no Porto, em 1858. Por volta de 1865 , inaugura a Fábrica de Cerâmica e Fundição das Devesas em Vila Nova de Gaia, obra que viria a ser um marco na indústria de cerâmica da região norte. Morreu a 7 de novembro de 1915, com 83 anos, sendo sepultado no jazigo onde estava a sua mulher.

Quando da redação do seu testamento, intitula-se como industrial e proprietario, residente na rua Mousinho Albuquerque, freguesia de Santa Marinha, do concelho de Gaia. A esposa indicara como lugar de residência logar das Devezas, freguesia de Santa Marinha e Vila Nova de Gaia. À época já a esposa havia morrido, razão para fazer testamento, tanto mais que o edifício estava terminado e faltava apenas mobilá-lo. Na verdade, no início do século XX, o casal iniciara uma política local de beneficência em prol dos pobres e operários, de que a construção de um asilo é uma parte apenas, ainda não explorada, e que motiva a nossa abordagem, no âmbito de um certo "filantropismo patronal" (Soeiro et al., 1995, p. 271), que incluía a construção de bairros sociais à volta das próprias unidades fabris (Machado, 2010), que incorporavam os materiais produzidos na edificação dos dois bairros, podendo ser também assumida como uma estratégia comercial.

É bem provável que, como defende Fernando Correia (2014), as atividades "filantrópicas" do casal se iniciassem antes, por volta de 1894, ano da inauguração da Creche e Jardim Escola, inicialmente sediada na rua Visconde das Devesas, dado que Almeida da Costa era membro associado da Associação das Creches de Santa Marinha, desde 1889. Esta associação surgiu de um grupo de notáveis do concelho "Clube dos Cartolas" onde, numa época em que a mulher acrescenta às lides domésticas o trabalho assalariado, um grupo de sócios deste Clube, com particular destaque para o Dr. Leopoldo José d'Oliveira Mourão, teve a ideia da criar uma creche em Gaia destinada ao cuidado das crianças, ou, como se podia ler no estatuto, que durante anos a regeu, para "receber, agasalhar e alimentar, durante o dia, os filhos das mães pobres, que trabalham fora dos domicílios, dando-Ihes assim a liberdade do tempo e de seus braços para poderem adquirir meios de sustentação."(F. A. da S. Correia, 2014, p. 138). A expressão é clara: eram pobres e não tinham alternativa senão acrescentar atividades fora do seio familiar. 
A 7 de Novembro de 1915, com a morte de António Almeida da Costa, já então viúvo, e mediante a vontade expressa no seu testamento, a gestão do património, onde consta o asilo, ficou sob a tutela de uma Comissão Administrativa à qual fora conferido o direito de, se tal se mostrasse aconselhável e conveniente, transferir a sua direção e manutenção para quem melhor pudesse garantir o seu bom funcionamento.

O facto de Emília ter falecido um ano antes da inauguração do asilo (faleceu em 1914 e o asilo foi inaugurado em 1915) não impediu que a mesma deixasse expresso no seu testamento o objetivo desta obra social, bem como as principais linhas orientadores de funcionamento da mesma. Assim o objetivo do asilo era o de "...receber e tratar carinhosamente, dentro dos limites que naturalmente lhe estão traçados, velhos de ambos os sexos, que não possam ganhar os meios de subsistência (...) que não sejam entrevados e lasaros"

Para além destas condições, o asilo destinava-se, preferencialmente, a acolher velhos da principal área de influência, o lugar das Devesas, para além de serem especialmente dedicados aos operários do complexo industrial:

"Dar-se-ha sempre a preferencia aos que residirem n'este logar das Devezas, pelo menos ha dous anos, $e$ aos que tiverem sido ou forem operarios nas fabricas de Ceramica e Fundição das Devezas por mim fundadas."

Uma atenção especial foi dada à administração do estabelecimento, que expressamente deveria sempre manter a sua natureza privada e impedir qualquer intervenção por parte do Estado. Aliás, esta é uma condição bem vincada, já que na falha de administradores, o estabelecimento deveria cessar funções:

O estabelecimento conservarás sempre a naturesa de particular, de modo que nem o Estado nem qualquer autoridade publica terão nele interferencia, a não ser a que se provem das leis que lhes conferem o direito de inspeção nos casos em que o bem geral assim o exige. Do contrario, ou pretendendo o Estado intervir diretamente na administração da herança ou dar a esta qualquer outro destino, haver-se-há por terminada a fundação ou instituição $o^{8}$.

\subsection{O Asilo para VelHos: dA fORMALIDADE À REALIDADE}

$O$ asilo tinha como fim receber velhos de ambos os sexos, pobres, desde que não fossem entrevados ou lázaros. Ou seja, não era um local preparado para receber incapacitados ou doentes, em grande medida porque teriam alguma autonomia e participação nas tarefas internas. Além destas condições, segundo o regulamento interno do Asilo, antes da admissão deveria ser feito um levantamento da informação do admitido referente aos seus costumes, qualidades, procedimentos anteriores e da altura da entrada ${ }^{9}$. A admissão no asilo estava sempre dependente da decisão da Comissão Administrativa, sendo decidida em reunião ordinária. A leitura do regulamento interno levanta uma série de questões que se prendem, sobretudo, com a dinâmica de funcionamento que subjaz à fundação desta instituição e ao próprio conceito de asilado. A situação de velhice, acrescida pela debilidade física, social e económica, é por si só uma etapa da vida humana (Esteves, 2017, p. 56), principalmente à época, de grande vulnerabilidade.

Admitidos no asilo, e em situação de pobreza e necessidade, os asilados teriam de se sujeitar a um conjunto de regras rigorosas para que o bom funcionamento fosse uma constante. A entrada no asilo assemelhava-se, a título comparativo, com o processo de entrada num estabelecimento prisional: primeiro são prestadas declarações, depois o admitido é lavado e vestido com a roupa da casa, ficando a roupa e os bens que trazia sob propriedade do asilo ${ }^{10}$. Aos asilados do sexo masculino é-lhes ainda cortada a barba e o cabelo. O uniforme que usavam era indispensável, sem o qual não poderiam sair do asilo (as saídas teriam de ser sempre previamente autorizadas).

O dia começava pelas seis horas da manhã, nos meses de novembro a abril, e às cinco horas da manhã nos meses de maio a outubro. A limpeza dos seus espaços era uma tarefa que os próprios asilados desempenhavam, a primeira do dia. As proibições regulamentadas evidenciam um ambiente de alguma conflitualidade ou de dificuldade de convívio de seres provenientes de vários meios, hábitos, procedimentos, que se pretendem uniformizar. De entre as proibições, salientam-se as seguintes:

Artigo 11. - É proibido a todos os asilados falar alto ou gritar, altercar ou rixar com os companheiros, escarnecer dos outros, usar de palavras ou ações indecentes, escarrar no chão, limpar as mãos à roupa da cama, à que trazem vestida ou às paredes, fumar nos dormitórios, fazer motim ou bulha, comer fora do refeitório e lançar no chão qualquer coisa que prejudique a limpeza que deve ser constante, ou conservar debaixo das camas qualquer objeto ${ }^{11}$. 
No que se refere à higiene pessoal, esta era feita mensalmente (banho mensal). O recolhimento seguia a mesma lógica do horário de levantar: nos meses de novembro a abril o recolher era às dezassete horas da tarde; nos meses de maio a outubro era às dezanove horas da tarde. A partir desta hora não havia lugar para mais conversas. Os passeios poderiam ser autorizados pela Comissão Administrativa, salvo casos em que o asilado estivesse inibido de sair. Nas situações em que o asilado regressasse ao asilo após a hora de recolhimento, a sua entrada era recusada.

O título "Dos Azilados e serviço do Azilo" é indicador do conjunto de deveres severos que confirmam a ideia de que participavam da sustentabilidade do Asilo. Na verdade, aos asilados, de ambos os sexos, estavam destinados trabalhos, aos quais teriam de se sujeitar, pelos seus superiores, desde que fossem compatíveis com as suas forças e idade ${ }^{12}$. Relativamente à alimentação, esta dividia-se em três refeições: o almoço, que seria às oito horas da manhã; o jantar, que seria às treze horas da tarde; e, a ceia, que teria lugar às dezanove horas da tarde ${ }^{13}$.

O carácter rigoroso do asilo implicava o cumprimento de princípios que eram expectáveis à época, entre os quais, o facto dos asilados não poderem conviver com as asiladas, sem especial autorização da diretora14. Mas o capítulo "Das correções e castigos" reúne um conjunto de castigos aplicados aos asilados em resultado de comportamento considerados desrespeitosos ou abusivos, tendo alguns destes sido identificados no Livro de Registos Individuais de Asilados (Secção Asilo), onde em algumas fichas individuais constam os castigos aplicados:

- Todos os internados são obrigados a respeitar os seus superiores, a quem devem obediência, sendoIhes lícito apresentar reclamações respeitosas, à Comissão Administrativa, quando as pretensões perante a directora, não tenham sido atendidas ${ }^{15}$;

- Todo aquele que faltar ao respeito aos seus superiores ou transgredir as disposições deste Regulamento, ou determinações da Comissão Administrativa, será punido, conforme a gravidade do facto, com suspensão de saída, por algum tempo, e no caso de reincidência com expulsão $0^{16}$. Igual pena sofrerá o internado que for encontrado a esmolar ou embriagado, e que tenha, com o seu procedimento e palavras, prejudicado o conceito e bom nome das Instituições que o agasalham e beneficiam;

- Os asilados podem também ser privados de quaisquer outras regalias, inclusive a de receber donativos, quando o prestígio da disciplina assim o exija ${ }^{17}$.
A título de exemplo, apresenta-se a transcrição de um castigo aplicado a uma asilada:

"Esta asilada foi castigada devido ao seu comportamento até ao dia 14 de Julho 1943, revoltou-se contra a Irmã e fez grande barulho de noite no dormitório. Esta asilada foi castigada pelo seu mau comportamento pelo espaço de um mês, começou em 30 de Dezembro e termina em fins de Janeiro de 1944. Novamente se prolongou o castigo por espaço de mais dois meses terminando no fim de Março de 1944."18

\subsection{Gestão do Asilo}

Além dos asilados, o pessoal assalariado do asilo tinha também um conjunto de deveres que deveriam ser estritamente cumpridos. A este respeito, esboçar um organograma da gestão do asilo, permite compreender como este se encontrava organizado em termos de hierarquia de funções. A sua construção ancorou-se nas informações contidas nas atas da Comissão Administrativa e no regulamento interno de funcionamento das instituições. Desta, resultou o seguinte organograma (Figura 1):

Figura 1. Organograma do Asilo António Almeida da Costa.

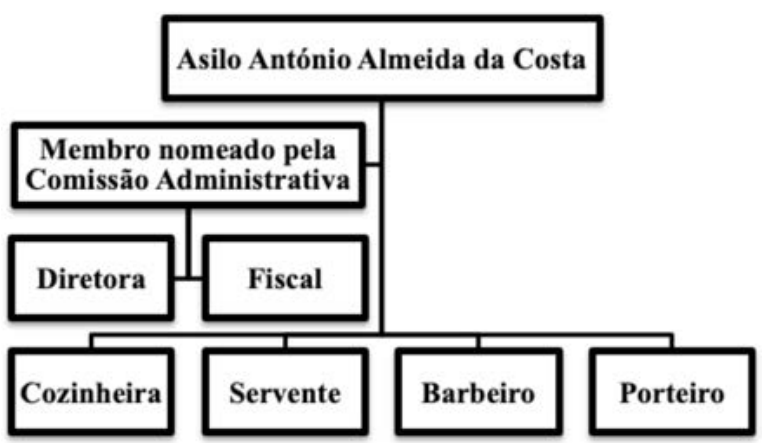

Fonte: Elaborado a partir das atas da comissão administrativa e do regulamento interno das instituições.

O pessoal assalariado do asilo ${ }^{19}$ é composto por uma cozinheira, uma servente, um barbeiro e um porteiro ${ }^{20}$. Todos eles estão subordinados à Diretora ${ }^{21}$, que é de nomeação vitalícia, e ao Fiscal, que por sua vez responde à figura responsável nomeada pela Comissão Administrativa e sobre o qual pouca informação foi encontrada. À cozinheira e à servente (a descrição das funções não estava detalhada como no caso da Diretora e do Porteiro) competia unicamente executar as funções atribuídas pela Diretora ${ }^{22}$. Ao barbeiro era exigida a sua presença semanal, no dia e à hora indicada pela Diretora ${ }^{23}$. 0 cargo de porteiro possuía a particularidade de poder ser desempenha- 
do por um asilado ou um estranho ao Asilo, desde que soubesse ler e escrever, tendo como funções ${ }^{24}$ :

- Não deixar sair qualquer internado sem autorização da Diretora ou da Comissão Administrativa e passar, aos do sexo masculino, uma revista rigorosa, para evitar extravios;

- Uma asilada seria encarregada, durante as horas de saída, de revistar as internadas que saíam do Asilo;

- Não deixar entrar pessoa alguma estranha ao Asilo, sem autorização superior;

- Não permitir a permanência de asilados na portaria ou átrio do edifício, fosse qual fosse o motivo.

A Diretora tinha, por sua vez, funções ${ }^{25}$ mais específicas, sendo as principais a de manter a disciplina no asilo, de inspecionar os alimentos e vestuário dos asilados, de fazer cumprir as regras de higiene e limpeza, efetuar a gestão económica do asilo, registar a admissão dos asilados, propor a nomeação do pessoal, reportar ao Presidente da Comissão Administrativa qualquer irregularidade, efetuar a lista de artigos a comprar, zelar pelo bom tratamento dos asilados e assistir à distribuição das rações.

Além destas atribuições, de foro mais organizacional do funcionamento do asilo, à Diretora competia ainda a visita, sem aviso prévio, das várias dependências do asilo como forma de inspecionar o bom funcionamento do mesmo. A organização e distribuição das tarefas dos asilados era feita pela Diretora, segundo o conhecimento que tinha, aquando o registo no momento de admissão, sobre as competências técnicas dos mesmos e a idade. Importa aqui fazer notar que dois terços do lucro resultante do trabalho dos asilados revertiam a favor do cofre das despesas do asilo. Do remanescente, cinquenta por cento seria para o fundo da instituição e os outros cinquenta por cento para o asilado. Contudo, existe a ressalva ${ }^{26}$ de que os cinquenta por cento destinados ao asilado seriam entregues em quantias e nas ocasiões que a Comissão Administrativa considerasse mais oportunas. A este respeito, é possível aqui identificar uma relação de dependência dos asilados face à Diretora e, muito em particular, à própria Comissão Administrativa. A situação de vulnerabilidade em que se encontram, seja de pobreza ou de marginalidade, é entendida como incapacidade de se auto cuidarem, ficando a cargo de outrem a gestão dos seus bens. No entanto, tinham capacidade para produzir rendi- mentos em determinadas ocupações, cuja natureza se desconhece.

A única proibição indicada à Diretora era a de não estar autorizada a proceder a obras ou reparos no edifício, bem como a requisição de bens que não tivessem como fim a utilização única e exclusiva por parte do asilo. Os vencimentos registados (anuais) variavam consoante o grau de complexidade e hierárquico da função: o Fiscal possuía o vencimento mais elevado, 360 escudos, seguido da Diretora com 120 escudos. Os restantes assalariados auferiam vencimentos bastante inferiores, como é o caso do Porteiro com 54 escudos, da Cozinheira com 48 escudos, da Servente com 36 escudos e do Barbeiro com 25 escudos.

\subsection{De Asilo a Hospital de TIFosos - UMA INICIATIVA PONTUAL}

Ainda que não estivesse escrito explicitamente em nenhum dos testamentos ou em outros documentos da autoria do casal, a ata da Comissão Administrativa (1 1 a reunião) da sessão do dia 2 de Janeiro de $1917^{27}$ refere a necessidade de organização do quadro dos empregados das instituições, segundo as condições impostas pelos testamentos dos grandes beneméritos, incluindo o quadro de pessoal do hospital. É apresentado num primeiro quadro um Diretor Clínico, um Dito Clínico (médico), um Enfermeiro, uma Enfermeira, uma Cozinheira, uma Dita ajudante, uma Criada para a banca, uma Criada para a enfermeira, uma Criada para o enfermeiro, um Trolha permanente e um Porteiro. Consoante a categoria de cada um, apresentava-se o vencimento anual: o Diretor Clínico auferia 250 escudos, o Dito Clínico 200 escudos, o Enfermeiro 144 escudos, a Enfermeira 120 escudos, o Trolha permanente 210 escudos, o Porteiro 54 escudos, a Cozinheira 72 escudos, a Dita ajudante 48 escudos, a Criada para o Enfermeiro 48 escudos e a Criada para a Enfermeira 36 escudos.

Verifica-se que, no final desse mesmo ano (1917), na sessão de 12 de Novembro, o Hospital ainda não funcionava "...devido às críticas que assediam das circunstâncias económicas." ${ }^{28}$. Apesar de não existir, efetivamente, um Hospital, na ata respeitante à sessão de 9 de março de 1918 o Presidente da Comissão Administrativa, Doutor Agostinho d'Almeida Rego lê a seguinte correspondência: 
Senhor Presidente dado conhecimento acerca do oficio do Senhor Administrativo sobre a adaptação do edficio do Azilo a hospital dos tifosos, de que havia empenhado as necessarias diligencias para evitar a sahida, embora temporaria dos azilados do edificio onde permanecem, mas não encontrando a autoridade administrativa predio adequado para o estabelecimento de um hospital, n'esta Vila, necessario ao combate da epidemia do tifo exantematico, teve de mobilisar aquele edificio deconformidade, e nos termos da lei de dez de janeiro de mil oitocentos e cincoenta e quatro como comunicou em seu oficio. ${ }^{29}$

Apesar do hospital não estar a funcionar oficialmente, os imperativos em termos de saúde pública, por não encontrarem outro edifício na cidade capaz de dar resposta aos doentes, obrigaram a que o asilo se transformasse temporariamente, em 1918, num hospital de tifosos (não havendo registos de quantos doentes acoIheu), não sendo a primeira vez que a região era atingida pelo tifo (Couto y Esteves, 2018, pp.363-369). No Porto do início do século XX, a falta de condições de salubridade e de higiene no espaço doméstico e na própria via pública foram um gatilho para a expansão galopante da epidemia de tifo exantemático ${ }^{30}$ (Tabela 1), considerada uma das maiores ameaças à saúde pública na cidade (Almeida, 2014, p. 488). Ricardo Jorge, Director-Geral da Saúde desde 1906 e pioneiro em Portugal na introdução das modernas técnicas e conceitos de saúde pública, referia que "soprava de Espanha a ameaça dum flagelo, o mais contagiante de todos, a querer repetir a ruidosa aparição de há 30 anos." (Jorge, 1912, p. 3). Foi o responsável pela organização de uma estratégia de saúde pública de combate à pandemia de gripe de 1918 (Pneumónica ou Gripe Espanhola), e contra as epidemias de tifo, varíola e difteria que surgiram como consequência das deficientes condições sanitárias do pós-guerra (Costa, 2018; A. L. Pereira \& Pita, 1993).

A consciência da saúde pública e do impacto desigual da doença, atingindo mais as classes pobres do que as outras, resultou do reconhecido trabalho de John Snow (Cameron \& Jones, 1984). Como alguns estudos apontam (2008, p. 473), a par da epidemia são registados avanços médicos e vastas obras de saneamento, além de campanhas de vacinação. Segundo os dados apurados, o tifo foi responsável por cerca de 1725 mortes em 1918 (F. da S. Correia, 1938, p. 197) e 1254 em 1919 (P. S. e Sousa et al., 2008), uma realidade que poderia ter sido pior se não estivessem em funcionamento medidas de controlo da epidemia por parte da Direção-Geral de Saúde (P. S. Sousa et al., 2009, p. 281).
Tabela 1. Caracterização do Tifo exantemático

\begin{tabular}{|c|c|}
\hline Dimensão & Descrição \\
\hline Epidemia & Tifo exantemático \\
\hline Datas & Dezembro de 1917 a agosto de 1919 \\
\hline Mortes & 1.481 , em 9.035 casos \\
\hline $\begin{array}{l}\text { Taxas de } \\
\text { Mortalidade }\end{array}$ & $\begin{array}{l}\text { 16,4\% (19,2\% em } 1918 \text { e } 9,8 \% \text { em } \\
1919)\end{array}$ \\
\hline $\begin{array}{l}\text { Causas } \\
\text { conhecidas } \\
\text { na época }\end{array}$ & $\begin{array}{l}\text { Bactéria do tifo exantemático, } \\
\text { identificada por H.T. Ricketts e Stanislaus } \\
\text { von Prowazek }\end{array}$ \\
\hline $\begin{array}{l}\text { Causas } \\
\text { atribuídas }\end{array}$ & $\begin{array}{l}\text { Um vírus transmitido pelos piolhos, } \\
\text { classes baixas pobres, com casas e } \\
\text { alimentação deficientes, em particular } \\
\text { pedintes e criminosos }\end{array}$ \\
\hline Transmissão & Piolhos \\
\hline $\begin{array}{l}\text { Medidas } \\
\text { Sanitárias }\end{array}$ & $\begin{array}{l}\text { Remoção dos piolhos, higiene e } \\
\text { desinfeção do corpo, das roupas e das } \\
\text { casas; banhos públicos obrigatórios e } \\
\text { queima das casas e de todo o } \\
\text { mobiliário e roupas. Isolamento dos } \\
\text { doentes, da respetiva família e vizinhos; } \\
\text { visitas sanitárias pelos delegados de } \\
\text { saúde acompanhados da polícia; escolas } \\
\text { encerradas }\end{array}$ \\
\hline
\end{tabular}

Fonte: Adaptado de Maria Antónia Almeida (Almeida, 2014, pp. 704-705).

Além das referências bibliográficas anteriormente referidas, a ata da sessão de 25 de março de 1918 demonstra ser, à data dessa sessão, o período crítico da epidemia que se fazia sentir por toda a cidade. Chega a ser referido "o progressivo desenvolvimento do epidémico tifo exantemático" ${ }^{31}$. Na verdade, os anos de 1918 e 1919 foram anos muito críticos para Portugal e para o Distrito do Porto, como refletem as estatísticas nacionais (a nível nacional, para o ano de 1917, 42 óbitos, no ano de 1918, 1725, ano de 1919, 1252 óbitos e em 1920 cerca de 125 óbitos) (Morais, 2008 , p. 220). Apesar do asilo ter sido encerrado pelo período de um ano, a epidemia do tifo fez-se sentir desde 1903 até durante a década vinte do século XX. Ainda que apenas se encontre, na documentação analisada, a referência ao tifo exantemático enquanto epidemia devastadora na cidade, a verdade é que outras epidemias se fizerem sentir neste período com impactos igualmente ou ainda mais devastadores, como é o caso da cólera, febre tifóide e tuberculose.

O controlo da epidemia é referenciado na sessão do dia 30 de setembro do mesmo ano, declarando o Presidente, Doutor Agostinho d'Almeida Rego, 
...que tendo diminuído, quase por completo, a epidemia do tifo exantemático, que durante bastante tempo se fez sentir neste concelho, este constava que brevemente o edifício do Asilo, que foi por ordem superior adoptado a hospital de tifosos, devia de ser entregue a estas instituições, acrescentando que tem enviado mensalmente para a Delegação de Saúde a nota do aluguer, devido à ocupação daquele edifício. "32.

Por este excerto, se verifica a urgência que a Comissão Administrativa tinha em recuperar as funções para as quais o asilo tinha sido inicialmente destinado. Aliás, isto vai ao encontro da necessidade em ver cumpridas as vontades dos beneméritos relativamente ao facto de que esta instituição se deveria manter sempre privada. A par disto, e talvez fruto das dificuldades económicas que já se faziam sentir ${ }^{33}$, o Presidente da Comissão solicitou à Delegação de Saúde o pagamento do aluguer dos edifícios. Na sequência da necessidade em recolocar os asilados no asilo é referido na sessão do dia 19 de novembro do mesmo ano, a urgência em desinfectar as salas para receber de novo os seus ocupantes, dado o perigo de contágio. Contudo, à data ainda o asilo não tinha sido entregue de novo à Comissão administrativa, situação que se encontra registada na sessão do dia 1 de Junho de 1919 . A criação de uma enfermaria e de um hospital efetivamente nunca viria a acontecer. As condições económicas da gestão do asilo não deixavam grande margem para serem mobilizados mais recursos económicos para outros fins. Em 1927, ano da aprovação dos regulamentos, verifica-se que o Hospital, por falta de recursos, ainda não funcionava, motivo por que não seria regulamentado. ${ }^{34}$

\subsection{OS ASILADOS: CARACTERIZAÇÃO SOCIODEMOGRÁFICA}

O reconhecimento dos que usaram o Asilo é possível ser feito através da análise dos registos de inválidos internados no asilo de António Almeida da Costa, no período que compreende os anos de 1917 a 1937, respetivamente ano de abertura do asilo e ano em que a Santa Casa da Misericórdia de Gaia toma posse do mesmo. Estes dados permitem um acompanhamento do asilado desde o momento que entra até à última observação que existe registada. Foram registadas 44 admissões (Tabela 2), 24 mulheres (54,5 \%) e 20 homens $(45,5$
\%) - realidade aproximada do peso dos homens e das mulheres na população residente do concelho segundo o Censo de 1911 -, com idade média, no momento de admissão, de 68,5 anos. Verifica-se, no entanto, que, em média, os homens entravam mais novos que as mulheres ( 66,5 anos) existindo registos da entrada de um com 43 anos de idade. No caso das mulheres, existe um registo de admissão no asilo com 91 anos o que está muito para além da esperança média de vida em Portugal em 1920 (o primeiro ano para o qual há dados para Portugal) de apenas 35,6 anos (OECD, 2014). Contudo, a idade média de falecimento dos asilados, 76,6 anos, é bastante superior à média estimada para a época, vislumbrando-se já um contínuo aumento da esperança média de vida.

Tabela 2. Idade e estado civil dos asilados no asilo António Almeida da Costa (1917-1937)

\begin{tabular}{|c|c|c|c|}
\hline \multirow{2}{*}{ Variáveis } & Masculinos & Femininos & Total \\
\hline & $\mathbf{N}$ & $\mathbf{N}$ & $\mathbf{N}$ \\
\hline Total & 20 & 24 & 44 \\
\hline \multicolumn{4}{|l|}{ Estado Civil } \\
\hline Solteiro/a & 3 & 7 & 10 \\
\hline Casado/a & 7 & 3 & 10 \\
\hline Viúvo/a & 9 & 13 & 22 \\
\hline \multirow[t]{2}{*}{ Divorciado/a } & 1 & 0 & 1 \\
\hline & $\begin{array}{l}\text { Média (D.P.) } \\
\text { / Min-Máx }\end{array}$ & $\begin{array}{l}\text { Média (D.P.) } \\
\text { / Min-Máx }\end{array}$ & $\begin{array}{l}\text { Média (D.P.) } \\
\text { / Min-Máx }\end{array}$ \\
\hline Idade & $\begin{array}{c}66,5(7,6) / \\
43-80\end{array}$ & $\begin{array}{c}70,3(10,4) / \\
50-91\end{array}$ & $\begin{array}{c}68,5(9,3) / \\
43-91\end{array}$ \\
\hline
\end{tabular}

Fonte: Elaborado com base no Livro de Inválidos Internados no Asilo.

O que também já é notório, em consonância com as várias estimativas e com a própria realidade atual, é que em média as mulheres viviam mais tempo que os homens, no caso dos asilados 5,4 anos a mais. 0 tempo de permanência no asilo era muito variável, registando uma estadia mínima de 1 ano e uma máxima de 18 anos (com uma média 7,1 anos), sendo fator influenciador a idade com que o asilado entrava. É também visível que as mulheres permaneciam mais tempo asiladas, já que viviam também, em média, mais anos que os homens, respetivamente 8,3 anos e 5,6 anos (Tabela 3). 
Tabela 3. Idade de Falecimento e tempo de permanência dos asilados no asilo António Almeida da Costa (1917-1937)

\begin{tabular}{|c|c|c|c|}
\hline \multirow{3}{*}{ Variáveis } & Masculinos & Femininos & Total \\
\cline { 2 - 4 } & $\begin{array}{c}\text { Média (D.P.) } \\
\text { Min-Máx }\end{array}$ & $\begin{array}{c}\text { Média (D.P.) } \\
\text { Min-Máx }\end{array}$ & $\begin{array}{c}\text { Média (D.P.) } \\
\text { Min-Máx }\end{array}$ \\
\hline $\begin{array}{c}\text { Idade } \\
\text { (Falecimento) }\end{array}$ & $\begin{array}{c}73,8(5,4) \\
62-81\end{array}$ & $\begin{array}{c}79,2(10,9) \\
55-97\end{array}$ & $\begin{array}{c}76,6(8,9) \\
55-97\end{array}$ \\
\hline $\begin{array}{c}\text { Permanência } \\
\text { (Anos) }\end{array}$ & $5,6(5,1)$ & $8,3(4,6)$ & $7,1(4,9)$ \\
$1-18$ & $1-16$ & $1-18$ \\
\hline
\end{tabular}

Fonte: Elaborado com base no Livro de Inválidos Internados no Asilo.

Na Tabela 4 é possível perceber que, para a maioria dos admitidos (21 dos 44), este se assumia com o último lugar em vida, permanecendo no mesmo até à data do seu falecimento. Identifica-se que dos restantes 23, 8 saíram por livre vontade (tendo 2 sido readmitidos ${ }^{35}$ ) e 2 foram expulsos.

Tabela 4. Motivo de saída do asilado no asilo António Almeida da Costa (1917-1937)

\begin{tabular}{|l|c|c|c|}
\hline \multirow{2}{*}{ Variáveis } & Masculinos & Femininos & Total \\
\cline { 2 - 4 } & $\mathbf{N}$ & $\mathbf{N}$ & $\mathbf{N}$ \\
\hline $\begin{array}{l}\text { Última } \\
\text { Observação }\end{array}$ & & & \\
\hline Faleceu & 10 & 11 & 21 \\
\hline $\begin{array}{l}\text { Saiu por sua } \\
\text { livre vontade }\end{array}$ & 2 & 6 & 8 \\
\hline Expulso/a & 2 & 0 & 2 \\
\hline \multicolumn{5}{|l}{} \\
\hline Readmitidos & 1 & 1 & 2 \\
\hline Sim & 19 & 23 & 42 \\
\hline Não &
\end{tabular}

Fonte: Elaborado com base no Livro de Inválidos Internados no Asilo.

Em consonância com o Censo de 1911 (Ministério das Finanças Português, 1913) os dados da naturalidade dos asilados (Tabela 5) expõem também a migração interna: dos 44 admitidos, 21 eram naturais do distrito do Porto, 12 do distrito de Viseu, 2 do distrito de Aveiro, 2 do distrito de Viana do Castelo, 1 do distrito de Faro, 1 do distrito de Portalegre, 1 do distrito de Vila Real, 1 do distrito de Évora e 1 do distrito de Setúbal. Destes, 39 residem no concelho de Vila Nova de Gaia, nomeadamente na freguesia onde se localiza o asilo, Santa Marinha (dos 39, 32 residem nesta freguesia), o que confirma, também, o critério determinado pelo casal fundador.
Tabela 5. Naturalidade e residência dos asilados no asilo António Almeida da Costa (1917-1937)

\begin{tabular}{|c|c|c|c|c|}
\hline \multirow{2}{*}{\multicolumn{2}{|c|}{ Variáveis }} & Masculinos & Femininos & Total \\
\hline & & $\mathbf{N}$ & $\mathbf{N}$ & $\mathbf{N}$ \\
\hline \multicolumn{2}{|c|}{$\begin{array}{l}\text { Naturalidade } \\
\text { (concelho) }\end{array}$} & & & \\
\hline \multicolumn{2}{|c|}{ Vila Nova de Gaia } & 7 & 4 & 11 \\
\hline \multicolumn{2}{|c|}{ Porto } & 1 & 2 & 3 \\
\hline \multicolumn{2}{|c|}{ Amarante } & 1 & 0 & 1 \\
\hline \multicolumn{2}{|c|}{ Arouca } & 0 & 1 & 1 \\
\hline \multicolumn{2}{|c|}{ Baião } & 1 & 0 & 1 \\
\hline \multicolumn{2}{|c|}{ Cinfães } & 1 & 1 & 2 \\
\hline \multicolumn{2}{|c|}{ Gondomar } & 0 & 1 & 1 \\
\hline \multicolumn{2}{|c|}{ Guimarães } & 1 & 0 & \\
\hline \multicolumn{2}{|c|}{ Loulé } & 0 & 1 & 1 \\
\hline \multicolumn{2}{|c|}{ Marco de Canaveses } & 1 & 2 & 3 \\
\hline \multicolumn{2}{|c|}{ Monforte } & 1 & 0 & 1 \\
\hline \multicolumn{2}{|c|}{ Penalva do Castelo } & 1 & 0 & 1 \\
\hline \multicolumn{2}{|c|}{ Peso da Régua } & 0 & 1 & 1 \\
\hline \multicolumn{2}{|c|}{ Ponte de Lima } & 1 & 0 & 1 \\
\hline \multicolumn{2}{|c|}{ Redondo } & 0 & 1 & 1 \\
\hline \multicolumn{2}{|c|}{ Resende } & 1 & 1 & 2 \\
\hline \multicolumn{2}{|c|}{$\begin{array}{l}\text { São João da } \\
\text { Pesqueira }\end{array}$} & 0 & 1 & 1 \\
\hline \multicolumn{2}{|c|}{ São Pedro do Sul } & 0 & 1 & 1 \\
\hline \multicolumn{2}{|c|}{ Santo Tirso } & 1 & 0 & 1 \\
\hline \multicolumn{2}{|c|}{ Sernancelhe } & 1 & 0 & 1 \\
\hline \multicolumn{2}{|c|}{ Sesimbra } & 1 & 0 & 1 \\
\hline \multicolumn{2}{|c|}{ Viana do Castelo } & 0 & 1 & 1 \\
\hline \multicolumn{2}{|c|}{ Vila da Feira } & 0 & 1 & 1 \\
\hline \multicolumn{2}{|c|}{ Vila de Mangualde } & 0 & 1 & 1 \\
\hline \multicolumn{2}{|c|}{ Viseu } & 0 & 2 & 2 \\
\hline Vou & zela & 0 & 1 & 1 \\
\hline Res & dência & & & \\
\hline Vila & Nova de Gaia & 19 & 20 & 39 \\
\hline & Santa Marinha & 14 & 18 & 32 \\
\hline$\frac{\pi}{y}$ & São Cristóvão & 3 & 0 & 3 \\
\hline 常 & Pedroso & 1 & 0 & 1 \\
\hline 亡ั & $\begin{array}{l}\text { Oliveira do } \\
\text { Douro }\end{array}$ & 0 & 2 & 2 \\
\hline Por & & 1 & 3 & 4 \\
\hline$\frac{\pi}{n}$ & Sé & 0 & 1 & 1 \\
\hline$\widetilde{D}_{00}$ & Paranhos & 1 & 1 & 2 \\
\hline 这 & Bonfim & 0 & 1 & 1 \\
\hline
\end{tabular}

Fonte: Elaborado com base no Livro de Inválidos Internados no Asilo. 
Quanto à ocupação (Tabela 6), das 24 mulheres, 13 eram donas de casa/domésticas, 2 cozinheiras, 1 lavadeira, 1 serviçal e 1 vendeira. É importante notar que nos registos, a ocupação "pobre" apenas surge em 3 asilados do sexo feminino. Relativamente aos homens, estes tinham ocupações muito diversificadas, sendo que, dos 20 asilados, 5 tinham sido trabalhadores/operários, 2 jardineiros, 2 criados de servir, 1 carpinteiro, 1 empresário de tabacos, 1 jornaleiro, 1 marmorista, 1 oleiro, 1 serralheiro, 1 sapateiro, 1 relojoeiro e 1 tanoeiro.

Tabela 6. Ocupação dos asilados no asilo António Almeida da Costa (1917-1937)

\begin{tabular}{|l|c|c|c|}
\hline \multirow{2}{*}{ Variáveis } & Masculinos & Femininos & Total \\
\cline { 2 - 4 } & $\mathbf{N}$ & $\mathbf{N}$ & $\mathbf{N}$ \\
\hline Ocupação & & & \\
\hline $\begin{array}{l}\text { Dona de Casa/ } \\
\text { Doméstica }\end{array}$ & 0 & 13 & 13 \\
\hline Cozinheira & 0 & 2 & 2 \\
\hline Carpinteiro & 1 & 0 & 1 \\
\hline $\begin{array}{l}\text { Empresário } \\
\text { Tabacos }\end{array}$ & 1 & 0 & 1 \\
\hline Jardineiro & 2 & 0 & 2 \\
\hline Jornaleiro & 1 & 0 & 1 \\
\hline Lavadeira & 0 & 1 & 1 \\
\hline Marmorista & 1 & 0 & 1 \\
\hline Oleiro & 1 & 0 & 1 \\
\hline Serralheiro & 3 & 0 & 3 \\
\hline $\begin{array}{l}\text { Trabalhador/ } \\
\text { Operário }\end{array}$ & 5 & 0 & 5 \\
\hline Sapateiro & 1 & 0 & 1 \\
\hline Relojoeiro & 1 & 0 & 1 \\
\hline $\begin{array}{l}\text { Serviçal/Criado de } \\
\text { Servir }\end{array}$ & 2 & 1 & 3 \\
\hline Vendeira & 0 & 1 & 1 \\
\hline Tanoeiro & 1 & 0 & 1 \\
\hline Pobre & 0 & 3 & 3 \\
\hline
\end{tabular}

Fonte: Elaborado com base no Livro de Inválidos Internados no Asilo.

A Tabela 7 ilustra o saldo (admissões e saídas) do asilo António Almeida da Costa desde o ano em que foi inaugurado, 1915, até ao ano de 1937. Os resultados demonstram que o ano inaugural foi aquele em que mais admissões foram registadas (9), registando novamente um valor de cinco admissões apenas em 1932. Podemos admitir que a capacidade máxima seriam os 9 admitidos, porque em lugar algum havia regulamentação acerca de um numerus clausus. Contudo, ao avaliar-se a relação anual entre entradas e saídas, o limite de 12 asilados parece admissível (como média), embora chegue ao número de 15 , verificandose um tendencial aumento desde 1932. Assim, durante o seu período de funcionamento, o asilo registava, em média, cerca de 2 admissões ao ano.

Tabela 7. Admissões e saídas no asilo António Almeida da Costa entre 1915 e 1937

\begin{tabular}{|c|c|c|c|}
\hline \multicolumn{4}{|c|}{ Asilo 1915-1937 } \\
\hline Ano & Admissões & Saídas & Saldo \\
\hline 1915 & 9 & 1 & 8 \\
\hline 1916 & 3 & 0 & 11 \\
\hline 1917 & 3 & 2 & 12 \\
\hline 1918 & 4 & 4 & 12 \\
\hline 1919 & 1 & 2 & 11 \\
\hline 1920 & 0 & 1 & 10 \\
\hline 1921 & 2 & 1 & 11 \\
\hline 1922 & 0 & 2 & 9 \\
\hline 1923 & 0 & 1 & 8 \\
\hline 1924 & 3 & 1 & 10 \\
\hline 1925 & 3 & 2 & 11 \\
\hline 1926 & 1 & 0 & 12 \\
\hline 1927 & 0 & 0 & 12 \\
\hline 1928 & 1 & 1 & 12 \\
\hline 1929 & 0 & 0 & 12 \\
\hline 1930 & 0 & 0 & 12 \\
\hline 1931 & 0 & 2 & 10 \\
\hline 1932 & 5 & 0 & 15 \\
\hline 1933 & 0 & 2 & 13 \\
\hline 1934 & 1 & 0 & 14 \\
\hline 1935 & 1 & 2 & 13 \\
\hline 1936 & 2 & 1 & 14 \\
\hline 1937 & 4 & 3 & 15 \\
\hline $\begin{array}{l}\text { Média } \pm \text { Desvio } \\
\text { Padrão }\end{array}$ & $1,9 \pm 2,2$ & $1,2 \pm 1,0$ & $11,6 \pm 12,0$ \\
\hline
\end{tabular}

Fonte: Elaborado com base no Livro de Inválidos Internados no Asilo.

\section{CONCLUSÕES}

O Asilo António Almeida da Costa, na freguesia de Santa Marinha em Vila Nova de Gaia, simboliza as 
ações caridosas que não se inserem no grupo daqueles que, habitualmente, a historiografia apelida de filantropos. Fazem parte do conjunto de patrões que desenvolveram ações de proteção aos seus trabalhadores, ainda que não estejam vinculadas unicamente a este universo. Surgiram numa época onde o trabaIho operário industrial era dominante no concelho e onde as condições de vida destes trabalhadores eram precárias. Os velhos, mais vulneráveis fisicamente, procuravam estas instituições como forma de amparo.

O hospital nunca surgiu referenciado no testamento cerrado de António Almeida da Costa. Por necessidade, aquando a epidemia do tifo exantemático (em 1918), por ordem da Direção-Geral de Saúde, o edifício do asilo foi transformado provisoriamente num hospital de tifosos (viria a ser uma única ala de enfermaria), uma vez que não existia na região uma infraestrutura com as mesmas condições. Nessa altura, o asilo encerrou temporariamente, uma vez que não estavam reunidas as condições de higiene necessárias. Um ano mais tarde, por volta do segundo semestre de 1919, o asilo abriu gradualmente. Contudo, os dados existentes nem dão informações concretas sobre entradas de doentes, nem se verifica ausência de registos.

Os regulamentos internos do asilo possibilitaram a reconstrução do seu funcionamento. Verificou-se a existência de regras de conduta rígidas e intransponíveis, assemelhando-se à rotina de uma prisão. Hora de levantar e hora de deitar, saída apenas com autorização, trabalhos obrigatórios com remuneração pontual e não obrigatória, visitas de familiares ou amigos apenas sob prévia autorização da Diretora e, ainda, inexistência de contacto entre asilados de sexo oposto. Não se conseguiu perceber que tipo de trabalhos poderiam realizar, porque em momento algum se conseguiu informação. Hipoteticamente, teria a ver com desempenhos internos.

A consulta dos registos existentes possibilitou traçar, dentro do possível, com as variáveis existentes, um perfil sociodemográfico dos admitidos no asilo. No universo das admissões registaram-se 44 admissões entre 1917 e 1937, dos quais 24 eram mulheres. Concluiu-se que o asilo era, para muitos destes (22) o último local em vida, sendo que acabariam, maioritariamente, por falecer neste espaço. A naturalidade dos asilados era muito diversa, pulverizando-se um pouco por todo o país, sinal de mobilidade geográfica para este concelho.

De forma geral, a constituição do asilo teve um papel determinante no apaziguar dos males, como a miséria, a pobreza e o desamparado das famílias do lugar das Devesas. Além da função, enquanto equipamento social de amparo na velhice, mitigaram os impactos da pobreza na população do lugar, dado que nas admissões do asilo se regista a entrada de "pobres". Além do asilo, parece ser negligenciado o importante serviço público que o Hospital, ainda que de carácter temporário, terá prestado no combate ao tifo exantemático em 1918 (embora não tenhamos encontrado dados objetivos), que auxiliaria no processo de cura e isolamento dos contagiados pela doença.

\section{NOTAS}

1 Para uma análise mais profunda das condições de pobreza no Portugal do início do século XX sugere-se a consulta de Léon Poinsard "Portugal Ignorado: estudo social, económico e político" (Poinsard, 1912) e Bento Craqueja "O povo portuguez" (Carqueja, 1916).

2 Ainda que, segundo Virgílio Borges Pereira (Pereira, 2003), fosse no período da implantação da República e do Sidonismo que se construiu o primeiro bairro social da cidade do Porto: o bairro Sidónio Pais, hoje Bairro Social da Arrábida, inaugurado em 1918 e acompanhado, em seguida, pela construção de quatro colónias operárias, entre 1915 e 1919.

3 Algumas das matérias aqui apresentadas fazem parte da Dissertação de Mestrado em História e Património da primeira autora intitulada "Asilo, Creche e Hospital (de crianças e velhos) D. Emília de Jesus Costa e António Almeida da Costa (1915-1937): dinâmica(s) e funcionalidade(s)",

defendida na Faculdade de Letras da Universidade do Porto (Pereira, 2019).

4 ADP, ADPRT, Paróquia de Santo Ildefonso, Registo de Casamentos, 1841-1859, fl 231.

5 Visita ao Cemitério Paroquial de Santa Marinha, no dia 15 de Fevereiro de 2019 (16 horas),

6 Testamento cerrado de Emília de Jesus Costa, datado de 12 de dezembro de 1901, Vila Nova de Gaia.

7 Testamento cerrado de Emília de Jesus Costa, datado de 12 de dezembro de 1901, Vila Nova de Gaia.

8 Testamento cerrado de António Almeida da Costa, datado de 17 de abril de 1915, Porto.

9 Art.o 3o do capítulo 1 do Regulamento Interno do Azilo, Creche e Hospital D. Emília de Jesus Costa e António Almeida da Costa, aprovado por alvará de 15/11/1927. 
10 Art.o 60 do capítulo 2 do Regulamento Interno do Azilo, Creche e Hospital D. Emília de Jesus Costa e António Almeida da Costa, aprovado por alvará de 15/11/1927.

11 Art.o 11을 do capítulo 2 do Regulamento Interno do Azilo, Creche e Hospital D. Emília de Jesus Costa e António Almeida da Costa, aprovado por alvará de 15/11/1927.

12 Art.o 16 - do capítulo 2 do Regulamento Interno do Azilo, Creche e Hospital D. Emília de Jesus Costa e António Almeida da Costa, aprovado por alvará de 15/11/1927.

13 Art.o $18^{\circ}$ do capítulo 2 do Regulamento Interno do Azilo, Creche e Hospital D. Emília de Jesus Costa e António Almeida da Costa, aprovado por alvará de 15/11/1927.

14 Art.o 170 do capítulo 2 do Regulamento Interno do Azilo, Creche e Hospital D. Emília de Jesus Costa e António Almeida da Costa, aprovado por alvará de 15/11/1927.

15 Art.o 280 do capítulo 2 do Regulamento Interno do Azilo, Creche e Hospital D. Emília de Jesus Costa e António Almeida da Costa, aprovado por alvará de 15/11/1927.

16 Art.o 29o do capítulo 2 do Regulamento Interno do Azilo, Creche e Hospital D. Emília de Jesus Costa e António Almeida da Costa, aprovado por alvará de 15/11/1927.

17 Art.o 30 o do capítulo 2 do Regulamento Interno do Azilo, Creche e Hospital D. Emília de Jesus Costa e António Almeida da Costa, aprovado por alvará de 15/11/1927.

18 Livro de Registos Individuais de Asilados (Secção Asilo),

19 O pessoal assalariado é escolhido de acordo com um concurso público - Art.o 21 do capítulo 3 do Regulamento Interno do Azilo, Creche e Hospital D. Emília de Jesus Costa e António Almeida da Costa, aprovado por alvará de 15/11/1927.

20 Art.o 24 do capítulo 5 do Regulamento Interno do Azilo, Creche e Hospital D. Emília de Jesus Costa e António Almeida da Costa, aprovado por alvará de 15/11/1927.

21 Art.o 22 do capítulo 3 do Regulamento Interno do Azilo, Creche e Hospital D. Emília de Jesus Costa e António Almeida da Costa, aprovado por alvará de 15/11/1927.

22 Art.o 25, seção 1 , do capítulo 5 do Regulamento Interno do Azilo, Creche e Hospital D. Emília de Jesus Costa e António Almeida da Costa, aprovado por alvará de 15/11/1927.

23 Art.o 26, seção 2, do capítulo 5 do Regulamento Interno do Azilo, Creche e Hospital D. Emília de Jesus Costa e António Almeida da Costa, aprovado por alvará de 15/11/1927.

24 Art.o 27, seção 3, do capítulo 5 do Regulamento Interno do Azilo, Creche e Hospital D. Emília de Jesus Costa e António Almeida da Costa, aprovado por alvará de 15/11/1927.

25 Art.o 23, nos 1ㅇ a 14ㅇdo do capítulo 4 do Regulamento Interno do Azilo, Creche e Hospital D. Emília de Jesus Costa e António Almeida da Costa, aprovado por alvará de 15/11/1927.
26 Art.o 24으, no12 do capítulo 4 dos Estatutos do Asylo, Creche e Hospital, particulares, instituídos pelos benemeritos $D$. Emília de Jesus Costa e António Almeida da Costa, datado de 20 de janeiro de 1916

27 Ata da Comissão Administrativa da sessão do dia 2 de Janeiro de 1917, em que estiveram presentes Aníbal Mariani Pinto, Albino Fernandes e Abílio de Castro. O primeiro tem o poder de presidente, o segundo de secretário e o terceiro de tesoureiro.

28 Ata da Comissão Administrativa da sessão do dia 12 de novembro de 1917, em que estiveram presentes o Senhor Doutor Agostinho d'Almeida Rego, estando presente o secretário António de Azevedo Maia, o Senhor Abílio de Castro, tesoureiro, e Basílio Ferreira de Macedo, na qualidade de vogal.

29 Ata da Comissão Administrativa da sessão do dia 9 de março de 1918.

30 Segundo Alexandra Esteves (2014, p. 175), também na região de Viana do Castelo foi referenciada, no dia 19 de Setembro de 1918, a presença do tifo e da gripe na vila, não dispondo de médico municipal. A história demonstranos que as altas taxas de mortalidade na Europa, nos finais do século XIX e nos inícios do século XX, se deveram essencialmente à febre tifóide, ao tifo exantemático, à varíola, ao sarampo e à difeteria (Morais, 2008, p. 227; Sousa et al., 2008)

31 Ata da Comissão Administrativa da sessão do dia 25 de março de 1918.

32 Ata da Comissão Administrativa da sessão do dia 30 de setembro de 1918.

$33 \mathrm{Na}$ ata da Comissão Administrativa da sessão do dia 12 de novembro de 1917 são referidas as dificuldades económicas.

34 Art.o 85 do capítulo 6 do Regulamento Interno do Azilo, Creche e Hospital D. Emília de Jesus Costa e António Almeida da Costa, aprovado por alvará de 15/11/1927.

35 Identificou-se na ata respeitante à sessão de 28 de novembro de 1917 da Comissão Administrativa esta situação, verificando-se que estes dois asilados, que saíram inicialmente por sua livre vontade, foram readmitidos advogando, na carta que escreveram, que foram operários da fábrica dos beneméritos e que se encontravam em situação de privação extrema, leia-se "sahiam por sua livre e expontanea vontade, ha aproximadamente trez mezes supondo que alguns pequenos rendimentos que possuiam chegassem para o seu sustento, no que se enganaram, pois talvez em breve estejam abraços com a miseria, pelas dificuldades da hora presente, e reconhecendo que só ali podem ter descanço e socego para os ultimos dias da sua vida, pretendem ser novamente recolhidos, logo que isso seja possivel, esperando que Vossas Excelencias atendam o seu pedido.". 


\section{BIBLIOGRAFÍA}

Almeida, Maria Antónia Pires de (2014), “As epidemias nas notícias em Portugal: cólera, peste, tifo, gripe e varíola, 1854-1918", História, Ciências, Saúde - Manguinhos, 21(2), pp. 687-708.

Amorim, Inês; Pinto, Sara (2018), "Pobreza e Caridade : As esmolas nos discursos e nas práticas da misericórdia do Porto , na época moderna", Via Spiritus, 25, pp. 53-89.

Araújo, Maria Marta Lobo de Araújo ; Esteves, Alexandra (2011), "Apoio privado à pobreza: A influência do "catolicismo social" no legado de Francisco Xavier da Cruz Araújo". En Araújo, Maria Marta Lobo de; Esteves, Alexandra (eds.), Marginalidade, Pobreza e Respostas Sociais na Península Ibérica (séculos XVI-XX), Porto, CITCEM, pp. 233-251.

Cameron, Donald ; Jones, Ian G. (1984), "John Snow, the Broad Street pump and modern epidemiology", International Journal of Epidemiology, 13(3), pp.376-378.

Carqueja, Bento (1916), O povo portuguez, Porto, Lello y Irmão.

Cascão, Rui (2011), "A habitação popular urbana”. En Mattoso, José (Ed.), História da vida privada em Portugal. A época comtemporânea.Volume 3, Lisboa, Temas e Debates, pp. 22-55.

Correia, Fernando António da Silva (2014), António Almeida da Costa - Industrial Humanista Filantropo, Vila Nova de Gaia, Santa Casa da Misericórdia de Vila Nova de Gaia.

Correia, Fernando da Silva (1938), Portugal Sanitario (Subsidios para o seu estudo), Lisboa, Direcção Geral da Saúde Pública.

Costa, Rui Manuel Pinto (2018), Ricardo Jorge: ciência, humanismo e modernidade (1st ed.), Coimbra, Imprensa da Universidade de Coimbra.

Dix, Steffen (2010), "As esferas seculares e religiosas na sociedade Portuguesa", Analise Social, 45(194), pp. 5-27.

Durães, Margarida (2019), Amélia de Orleães. A rainha mal amada, Lisboa, Temas e Debates.

Esteves, Alexandra (2014), "O impacto da pneumónica em alguns concelhos do Alto Minho", CEM: Cultura, Espaço y Memória, 5, pp. 165-181.

Esteves, Alexandra (2015a), “Da caridade à filantropia: o auxílio aos presos pobres da cadeia de Ponte de Líma no século XIX", Estudios Humanísticos. Historia, 7, pp. 221-236.

Esteves, Alexandra (2015b), "Fontes para o estudo da pobreza no norte de Portugal oitocentistas", Estudios Humanísticos. Historia, 13, pp. 165-185.

Esteves, Alexandra (2017), "Entre a Caridade e a Assistência: a Criação e o Funcionamento do Hospital da Caridade em Viana do Castelo (Séculos XVIII-XIX)", História: Questões y Debates, 65(1), pp. 55-74.

Esteves, Alexandra (2018), "A força dos pobres e a condição humana: vigiar, acudir e prevenir". En Amorim, Inês (Ed.), Sob o Manto da Misericórdia: Contributos para a História da Santa Casa da Misericórdia do Porto. Volume III (18201910), Coimbra, Edições Almedina, pp. 261-388.

Fernandes, António Teixeira (2018), “Metamorfoses da Pobreza na Época Contemporânea". En Amorim, Inês (Ed.), Sob o Manto da Misericórdia: Contributos para a História da Santa Casa da Misericórdia do Porto. Volume IV (1910 aos nossos dias), Coimbra, Edições Almedina, pp. 59-187.

Jorge, Ricardo (1912), "A epidemia tífica de Lisboa em 1912". En Arquivos do Instituto Central de Higiene (Secção de Higiene), pp. 131-188.

Lopes, Maria Antónia (2000), Pobreza, Assistência e Controle Social em Coimbra (1750-1850), Coimbra, Palimage Editores.

Lopes, Maria Antónia (2013), “Os socorros públicos em Portugal, primeiras manifestações de um Estado-Providência (séculos XVI-XIX)", Revista Estudos Do Século XX, 13, pp. 257-280.

Lopes, Maria Antónia. ; Roque, João Lourenço (2000), "Pobreza, assistência e política social em Portugal nos Sécs. XIX e X - perspectivas historiográficas". En A Cidade e o Campo. Colectânea de estudos, pp. 63-83.

Machado, Maria do Rosário (2010), "Bento Carqueja e o Movimento de Beneficência e Filantropia de Finais do Século XIX". En, Araújo, Maria Marta Lobo; Ferreira, Fátima Moura; Esteves, Alexandra (Eds.), Pobreza e Assistência no Espaço Ibérico (Séculos XVI-XX)), Porto, CITCEM, pp. 223-236.

Ministério das Finanças Português. (1913), Censo da População de Portugal no $1 .^{\circ}$ de Dezembro de 1911, Lisboa, Imprensa Nacional.

Morais, David (2008), "Tifo epidémico em Portugal: um contributo para o seu conhecimento histórico e epidemiológico", Medicina Interna, 15(3), pp. 214-229.

OECD. (2014), How Was Life?, Paris, OECD.

Paiva, José Pedro ; Fontes, Paulo (2002), “Organização e Metodologia". En Portugaliae Monumenta Misericordiarum, Lisboa, Centro de Estudos de História Religiosa da Faculdade de Teologia - Universidade Católica Portuguesa.

Pereira, Ana Leonor ; Pita, João Rui (1993), "Liturgia higienista no século XIX - pistas para um estudo", Revista de História Das Ideias, 15, pp. 437-559.

Pereira, Catarina Nogueira (2019), Asilo, Creche e Hospital (de crianças e velhos) D. Emília de Jesus Costa e António Almeida da Costa (1915-1937): dinâmica(s) e funcionalidade(s), Porto, Faculdade de Letras da Universidade do Porto.

Pereira, Virgílio Borges (2003), "Uma imensa espera de concretizações ... Ilhas, bairros e classes laboriosas brevemente perspectivados a partir da cidade do Porto", Sociologia, pp. 139-148.

Poinsard, Léon (1912), Portugal ignorado: estudo social, economico e politico, Porto, Magalhães y Moniz, I.da.

Portela, Ana Margarida (2007), "A Fábrica de Cerâmica das Devesas - percurso biográfico dos seus principais artistas". 
En Artistas e Artifices e a Sua Mobilidade No Mundo de Expressão Portuguesa. Actas Do VII Colóquio Luso -Brasileiro, pp. 41-48.

Reis, Maria de Fátima (2016a), “Educação e Assistência em Portugal: ritmos e evolução", Saber y Educar, 21(21), p. 148.

Reis, Maria de Fátima (2016b), "Ribeiro, Victor Maximiano", Dicionário de Historiadores Portugueses. Da Academia Real das Ciências ao final do Estado Novo [em línha], disponível em: http://dichp.bnportugal.pt/imagens/ribeiro_victor.pdf, [consultado em 15/11/2019].

Ribeiro, Victor (1907), História da Beneficência Pública em Portugal, Coimbra, Imprensa da Universidade.

Rosas, Fernado ; Rollo, Maria Fernanda (2009), História da Primeira República Portuguesa, Lisboa, Tinta-da-China.

Sanglard, Gisele; Lopes, Maria Antónia (2018), "Pobreza e assistência: debates historiográficos", Tempo, 24(2), pp. 280-284.
Silva, Teresa Paula Garcia Rodrigues (2016), A primeira escola de Serviço Social em Portugal : o projeto educativo fundador e a configuração do campo de conhecimento (1935-1955), Lisboa, Universidade Lusíada de Lisboa.

Soeiro, Teresa ; Alves, Jorge Fernando. ; Lacerda, Silvestre, ; Oliveira, Joaquim (1995), "A cerâmica portuense : evolução empresarial e estruturas edificadas", Portugália, 16, pp. 203-287.

Sousa, Paulo Silveira e; Castro, Paula; Lima, Maria Luísa; Sobral, José Manuel (2008), "Responder à epidemia : estado e sociedade civil no combate à gripe pneumonica (1918-1919)", Revista de História Das Ideias, 29, pp. 469-500.

Sousa, Paulo Silveira e.; Sobral, José Manuel; Lima, Maria Luísa, Castro, Paula (2009), "A epidemia antes da pandemia: o tifo exantemático no Porto (1918-19)", En A pandemia esquecida: Olhares comparados sobre a Pneumónica (1918/19), Lisboa, Imprensa de Ciências Sociais, pp. 279-290. 